\title{
HEAVY METAL INTERRELATIONSHIPS IN SOIL IN THE PRESENCE OF TREATED WASTE WATER
}

\author{
I.K. KALAVROUZIOTIS ${ }^{1, *}$ \\ P.H. KOUKOULAKIS ${ }^{2}$ \\ A.H. PAPADOPOULOS ${ }^{3}$
}

\author{
${ }^{1}$ Department of Environmental and Natural Resources \\ Management, University of Ioannina, G.Seferi 2, Agrinion-Greece \\ ${ }^{2}$ Assoc. Researcher, Soil Science Institute \\ NAGREF, Altladidos 8, GR-544 54, Thessaloniki, Greece \\ ${ }^{3}$ NAGREF, Soil Science Institute, of Thessaloniki \\ GR-570 01,Thermi, Thessaloniki, Greece
}

Received: $17 / 09 / 08$

Accepted: 18/09/09 *to whom all correspondence should be addressed: e-mail: ikalavru@cc.uoi.gr

\begin{abstract}
An experiment was conducted in a greenhouse located in Agrinion, Greece, in order to study the effect of the treated municipal wastewater (TMWW) on the soil heavy metal interactions, in comparison to ordinary well irrigation water, denoted as control. The ultimate aim was the establishment of sound scientific basis for the TMWW reuse in the irrigation of vegetable production. A randomized block design was used including TMWW and the control, in six replications, the vegetable of Brassica oleracea var. Gemmifera (Brussels sprouts) being used as a test crop.

The following were found:

Forty interactions took place in the soil between heavy metals $\mathrm{Pb}, \mathrm{Ni}, \mathrm{Co}, \mathrm{Cd}, \mathrm{Cu}$ and $\mathrm{Zn}$. Of these, 11 were significant under both the TMWW and the Control, respectively. Also, under only TMWW 15 interactions or $37.5 \%$ were statistically significant, while under the Control 21 or $52.5 \%$. It was also shown that the effect of TMWW on most of the statistically significant interactions between heavy metals, did not differ significantly from that of the control, suggesting that from this point of view, the TMWW could be used for reuse in vegetable irrigation, provided that health risk related to microbiological factor is taken into account.
\end{abstract}

KEYWORDS: Heavy metal, interaction, treated wastewater, reuse.

\section{INTRODUCTION}

The reuse of the treated municipal wastewater (TMWW) is a multifactor problem, related to social, spatial, economic and environmental criteria, each of these including a number of subcriteria. The present paper aims at an ecologically sound reuse of the TMWW, and therefore it will focus on its effects on soil heavy metals, as well as on their interactions, which by themselves, constitute an environmental quality factor, related to the decision making with respect to the TMWW reuse for crop irrigation.

As the environment involves the soil and the higher plant life, the TMWW reuse is directly associated with environmental quality, because by necessity, it is in an immediate contact with the soil-plant system, and consequently it may have variable effects on it (Chang et al., 1998). Therefore, the detailed study of the TMWW impact on the chemical, physical and biological properties of soil as well on its macro, microelements and especially heavy metal content and their interactions, need special attention. As the TMWW is a carrier of the above elements, its long term use may result in heavy metal accumulation in the soil. Furthermore, various interactions, especially among heavy metals, may take place, which enhance the previously mentioned accumulation, not only in the soil, but also in the plant tissues as well, depending on the extent of their synergism and antagonism, creating a potential risk factor for the consumer's health (Alloway, 1995). 
Preliminary studies with respect to the effects of TMWW on Brassica oleracea var. Italica (Broccoli), had shown that the reuse of TMWW increased the heavy metal content in the soil (Kalavrouziotis et al., 2008).

Also, it was found the TMWW could act as a factor that intensified some of the interactions between heavy metals as well as macro and microelements in the soil and plants (Kalavrouziotis et al., 2008a; 2008b). These interactions, could increase or decrease the level of the interacting heavy metals, depending on whether they were synergistic or antagonistic. Also, they could take place not only in the soil but in the plant, and especially in its various organs i.e. roots, leaves, and heads or sprouts, thereby, contributing to the spatial distribution of the heavy metals in the plant, an issue of great importance, as it is related to human health (Kalavrouziotis et al., 2008a; Alloway, 1995).

In our previous work it was found that under the effect of the TMWW, the heavy metal interactions in the soil may increase or decrease statistically significantly the level of each other, depending on their synergistic or antagonistic nature. The relevant information in the literature concerning the interactions of the heavy metals under the application of TMWW, not to mention their effect on plant growth, is very scarce. Traditionally, the heavy metal impact on plant growth is examined basically in terms of total bioavailable metal level or concentration in the soil. Obviously, this level originates from various sources such as weathering of local minerals, organic matter breaking down, application of sludge and wastewater, as well as from the heavy metal interactions. Consequently it is expected that the interrelationships between heavy metals may have a variable impact on the environmental quality, and on plant growth.

With the term "heavy metal" it is referred to those metals which have a density $>6 \mathrm{~g} \mathrm{~cm}^{-3}$ (Phipps, 1981). The heavy metals are also known as "trace metals" (Alloway, 1995; KabataPendias and Pendias, 1995).

The treated municipal wastewater is basically a carrier of plant nutrients (N,P,S, etc) and generally has low levels of heavy metals $(\mathrm{Pb}, \mathrm{Cd}, \mathrm{Ni}, \mathrm{Co}, \mathrm{Cr}$, etc). According to experiments conducted by Sheikh et al. (1998), long term environmental impacts of reclaimed wastewater reuse for the irrigation of crops, appeared to be minimal. Though generally domestic wastewaters do not contain high levels of heavy metals, occasionally however, they may contain high levels of these metals owing to non-point illegal connections to the sewage system, and metal pipes erosion.

Experimental results obtained by Kalavrouziotis et al. (2008), using TMWW for irrigation of Brassica oleracea var. Italica (Broccoli), resulted in the accumulation of $\mathrm{Cd}, \mathrm{Pb}$, and $\mathrm{Zn}$ in both soil and plants, especially in the heads i.e. the edible plant part. Though the TMWW was of domestic origin, the presence of heavy metals was attributed to probable non-point pollution sources, illegally connected to the sewage system.

An important aspect of TMWW reuse, which has not been given due attention, is the study of the interactions between essential nutrients and heavy metals under the effect of the TMWW, which by itself is a carrier of such elements. Similarly the effect of these interactions on the nutrient and heavy metal levels in the soil and in the plants, have not been investigated in detail so far

The relevant information on the effect of TMWW on the heavy metal interactions in the soil is very limited, and therefore more work is necessary to shed light on this aspect of TMWW reuse, which may be an important factor in decision making with respect to applying the TMWW as an alternative water source for vegetable irrigation.

In view of the fact that the TMWW reuse may add to the soil significant quantities of the above essential nutrients and heavy metals, the aim of the present work is to study the impact of TMWW on the heavy metal interactions in the soil, which had previously been cultivated with Brassica oleracea var. Gemmifera (Brussels Sprouts), the ultimate goal being to establish the necessary scientific basis for the reuse of TMWW in the irrigation of Brussels sprouts, and possibly of other vegetables. 


\section{MATERIALS AND METHODS}

An experiment was conducted in a greenhouse using a Statistical Design of Randomized Blocks, located at the University of loannina, Department of Environmental Management and Natural Resources, Agrinion Greece.

The general purpose of the experiment was to study the effects of the Treated Municipal Wastewater (TMWW) on soil properties, macro- and micronutrients, and heavy metal content, as well as on the inorganic composition of Brussels sprouts plant parts (roots, leaves and sprouts), with a view to examine the possibility off the TMWW reuse, for the irrigation of vegetables.

The statistical Design used, included two sources of irrigation water, (a) TMWW and (b) control, (ordinary well irrigation water), while the vegetable Brassica oleracea var. Gemmifera (Brussels Sprout) was used as a test plant.

The experiment was conducted in six replications, with a total of $2 \times 6=12$ experimental plots of $2.5 \times 1.8 \mathrm{~m}^{2}$ size. The plots were separated by dikes of $10 \mathrm{~cm}$ height. Brussels sprouts plants were transplanted in rows, the distance between them being $0.8 \mathrm{~m}$, while between the plants in the row $0.5 \mathrm{~m}$.

Transplanting was made on December 11, 2005, and harvesting of the sprouts 16 weeks after transplanting, i.e. April 20, 2005. The Treated Municipal Wastewater used, was supplied by the Biological Treatment Plant of Messolongion, located $3 \mathrm{kms}$ away from the town, adjacent to the river "Koukos".

The TMWW and the "control" were applied at the 50-60\% depletion of the available soil water, which was found by regular soil sampling and determination of moisture by drying the samples at $105^{\circ} \mathrm{C}$.

In total, the TMWW and Control, were applied nine times during the growth period at a rate of $30 \mathrm{~L}$ per $4.5 \mathrm{~m}^{2}$ at each irrigation, or $867 \mathrm{~mm}$ per ha. The application of the TMWW was done by means of a special hand operated sprinkler.

Composite soil samples from 0-30 cm depth were taken before the application of the TMWW and control, during the following periods: a) shortly before the commencement of the experiment, b) 8 weeks after transplanting and c) 16 weeks after transplanting (just before harvesting). The samples were prepared by being air dried, ground, sieved, and stored for chemical analysis.

The soil analytical data obtained with respect to the heavy metals, was statistically processed by means of regression analysis, ANOVA and t-test, in order to study the heavy metal interactions and their impact on the environment (Kalavrouziotis et al., 2008a).

\subsection{Chemical analyses 2.1.1 Soil analysis}

Soil analysis was done as follows: For the determination of available $\mathrm{P} 2.5 \mathrm{~g}$ of ground soil sample was extracted in $100 \mathrm{ml}$ of $0.5 \mathrm{M} \mathrm{NaHCO}_{3}$ after shaking steadily for 30 min. The $\mathrm{P}$ in solution was determined by developing the blue phosphomolybdate complex and its intensity was measured colorimetrically (Olsen et al., 1954). Available K was determined by extracting $2.5 \mathrm{~g}$ of soil in $50 \mathrm{~mL}$ of $1 \mathrm{M} \mathrm{MNH}_{4} \mathrm{Ac}, \mathrm{pH} 7.0$ (Lanyon and Heald,1982), and the $\mathrm{K}$ was measured by flame photometry. The soil micronutrients $\mathrm{Mn}, \mathrm{Zn}, \mathrm{Cu}$ and $\mathrm{Fe}$, and the heavy metals $\mathrm{Pb}, \mathrm{Ni}$, Co and $\mathrm{Cd}$, were extracted by using $20 \mathrm{~g}$ of soil in $40 \mathrm{ml}$ of $0.005 \mathrm{M}$ DTPA solution, and measured by means of Atomic Absorption Spectrophotometer, using a Variant AAS type (AA-IO) (Sakata, 1987). The $\mathrm{EC}, \mathrm{CaCO}_{3}$ organic matter (OM) and $\mathrm{pH}$ were determined by the methods suggested by Page et al. (1982).

\subsubsection{Irrigation water and TMWW analysis}

The well irrigation water and the TMWW were analyzed before their application by methods suggested by AOAC (1996) as follows: $\mathrm{pH}$ was determined electrometrically by means of a commercial pH-meter, while SAR was calculated (Richards, 1954). 
Total $\mathrm{N}$ was found by the Kjeldhal method i.e. by digesting a water and TMWW sample with $\mathrm{H}_{2} \mathrm{SO}_{4}$ to convert organic $\mathrm{N}$ to $\mathrm{NH}_{3}$, followed by distillation after alkanization and the total $\mathrm{N}$ being determined titrimetrically. $\mathrm{Cl}^{-}$anions were determined in $100 \mathrm{ml}$ of irrigation water or treated municipal wastewater, to which $1 \mathrm{~mL}$ of indicator-acidified was added-composed of

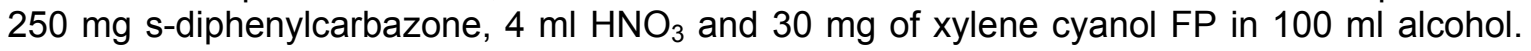
Then the solution was titrated with $0.0141 \mathrm{~N} \mathrm{Hg}\left(\mathrm{NO}_{3}\right)_{2}$ to definite purple end point.

$\mathrm{Ca}$ and $\mathrm{Mg}$ were measured by titration with ethyldiaminetetraacetic acid (Versenate) (Richard 1954). Ammonium acetate and dispersed organic matter were removed from the sample prior to titration with versenate. Evaporation of an aliquot of the water or TMWW to dryness followed by treatment with aqua regia (3 parts of conc. $\mathrm{HCl}$ and 1 part of conc. Nitric acid). The residue was dissolved in a quantity of water equal to the original volume of the aliquot, taken for treatment. First Ca was determined by placing a $5 \mathrm{~mL}$ aliquot and by diluting it with distilled water to approximately $25 \mathrm{ml}$. Then 5 drops of the $4 \mathrm{~N} \mathrm{NaOH}$ were added, and approximately $50 \mathrm{~mL}$ of ammonium purpurate indicator composed of $0.5 \mathrm{~g}$ of ammonium purpurate in $100 \mathrm{~g}$ of powered potassium sulfate. The solution was then titrated with versenate $0.01 \mathrm{~N}$ using a $10 \mathrm{ml}$ microburet, the end of the titration being determined by the color change from orange to lavender or purple. In turn, $(\mathrm{Ca}+\mathrm{Mg})$ was determined in an aliquot of $5 \mathrm{~mL}$, which was pipeted into a 125 Erlenmeyer flask. It was diluted to approximately $25 \mathrm{mLI}$ and $0.5 \mathrm{~mL}$ (10 drops) of the ammonium chloride-ammonium hydroxide buffer solution was added, and also 3-4 drops of Eriochrom black T indicator, composed of $0.5 \mathrm{~g}$ of Eriochrom T indicator (F241), $4.5 \mathrm{~g}$ of hydroxylamine hydrochloride in $100 \mathrm{ml}$ of $95 \%$ alcohol. and the solution was titrated with versinate. The calculations were made by means of the following relation: $\mathrm{Ca}$ or $(\mathrm{Ca}+\mathrm{Mg})$ in $\mathrm{meq}^{-1}=(\mathrm{mL}$ of versinate solution used $\mathrm{x}$ Normality of versinate $\times 1000) \mathrm{mL}^{-1}$ of aliquot used. The $\mathrm{K}$ in water or in the wastewater was determined by pretreatment in a buffer solution, and it was determined by using atomic absorption spectrophotometer.

Total $P$ was determined by digesting an aliquot of the sample with persulfate. The $P$ was measured by direct colorimetric analysis by developing the antimony phosphomolybdate complex, being reduced to intensely blue color by means of ascorbic acid. The color intensity was measured colorimetrically. The water $\mathrm{Fe}, \mathrm{Mn}, \mathrm{Zn}, \mathrm{Cu}$ and $\mathrm{Cr}$ contents were determined by filtering a known volume of the sample through $0.45 \mu \mathrm{m}$ membrane filter. The membrane with the residue was then transferred into a $250 \mathrm{ml}$ beaker, and $3 \mathrm{ml}$ of $\mathrm{HNO}_{3}$ were added. They were covered with watch glass and heated gently to dissolve the membrane. The heat was then increased to evaporate the solution to dryness. After cooling, $3 \mathrm{ml}$ of $\mathrm{HNO}_{3}$ were added until digestion was complete. Then $2 \mathrm{ml}$ of $\mathrm{HCl}(1+1)$ were added and reheated gently to dissolve the residue. The watch glass and the baker were washed with $\mathrm{H}_{2} \mathrm{O}$ and the solution was filtered. The filtrate was diluted to concentration within the range of the instrument. Then the metals in solutions were determined by means of an Atomic Absorption Spectrophotometer by setting the instrument the following wave lengths: $\mathrm{Fe}=248.34 \mathrm{~nm}$, $\mathrm{Mn}=6274.5 \mathrm{~nm}, \mathrm{Zn}=213.9 \mathrm{~nm}, \mathrm{Cu}=324.7 \mathrm{~nm}$, and $\mathrm{Cr}=357.9 \mathrm{~nm}$.

Arsenic (As) was determined by evaporating $0.5 \mathrm{I}$ to dryness, and by adding a small quantity of $\mathrm{NaCO}_{3}$. The filter with the residue was then washed thoroughly with hot water. The alkaline filtrate was diluted to definite volume, and it was used for the determination of the As. The following AOAC (1996).

Soluble B was determined in the irrigation water without pretreatment, and in the treated wastewater by pretreatment of the sample, i.e. by filtering through $0.4-0.45 \mu \mathrm{m}$ filter and by acidification of the filtrate with $\mathrm{HNO}_{3}$ up to $\mathrm{pH}<2.0$. Curcumine (Eastman No 1179) was used for the development of the red color and its intensity was measured by means of a spectrophotometer at $540 \mathrm{~nm}$, with minimum light path of $1 \mathrm{~cm}$ (APHA, 1995).

Sodium $(\mathrm{Na})$ in the wastewater was determined by pretreatment following the same procedure mentioned above for the $\mathrm{B}$, and the concentration of $\mathrm{Na}$ in the filtrate was measured by means of flame photometer. The relevant analytical data are given in Table 1. 
Table 1. Chemical characteristics of the two water sources used i.e. "Control" and "TMWW"

\begin{tabular}{|c|c|c|c|c|}
\hline \multirow{3}{*}{$\begin{array}{c}\text { Chemical } \\
\text { characteristics }\end{array}$} & \multicolumn{4}{|c|}{ Applied Treatments } \\
\hline & \multicolumn{2}{|c|}{ Control $(n=9)$} & \multicolumn{2}{|c|}{ TMWW $(n=9)$} \\
\hline & Mean & $\begin{array}{l}\text { Standard } \\
\text { deviation }\end{array}$ & Mean & $\begin{array}{l}\text { Standard } \\
\text { deviation }\end{array}$ \\
\hline $\begin{array}{l}\text { Conductivity } \\
\mu \mathrm{S} \mathrm{cm}^{-1}\left(25^{\circ} \mathrm{C}\right)\end{array}$ & 261.67 & 30.688 & 1305.22 & 242.975 \\
\hline $\mathrm{pH}$ & 8.38 & 0.280 & 7.56 & 0.554 \\
\hline $\mathrm{SAR}^{\mathrm{a}}$ & 0.38 & 0.052 & 4.29 & 0.247 \\
\hline $\mathrm{N}\left(\mathrm{mg} \mathrm{l}^{-1}\right)$ & 0.63 & 0.302 & 11.71 & 3.440 \\
\hline$P\left(\mathrm{mg} \mathrm{l}^{-1}\right)$ & 0.05 & 0.042 & 0.64 & 0.328 \\
\hline $\mathrm{K}\left(\mathrm{mg} \mathrm{l}^{-1}\right)$ & 0.88 & 0.164 & 16.14 & 4.903 \\
\hline $\mathrm{Ca}\left(\mathrm{mg} \mathrm{l}^{-1}\right)$ & 49.03 & 6.106 & 90.74 & 10.760 \\
\hline$M g\left(\mathrm{mg} \mathrm{l}^{-1}\right)$ & 4.2 & 0.299 & 21.63 & 3.606 \\
\hline $\mathrm{Fe}\left(\mu \mathrm{g} \mathrm{I}^{-1}\right)$ & 35.56 & 16.667 & 102.89 & 80.901 \\
\hline $\mathrm{Na}\left(\mathrm{mg} \mathrm{l}^{-1}\right)$ & 10.22 & 1.394 & 175.56 & 16.576 \\
\hline $\mathrm{Mn}\left(\mu \mathrm{g} \mathrm{I}^{-1}\right)$ & 4.11 & 2.147 & 84.54 & 62.954 \\
\hline $\mathrm{B}\left(\mathrm{mg} \mathrm{l}^{-1}\right)$ & 0.67 & 0.1 & 1.18 & 0.303 \\
\hline $\mathrm{Cl}\left(\mathrm{mg} \mathrm{l}^{-1}\right)$ & 14.96 & 2.351 & 290.36 & 94.984 \\
\hline $\mathrm{Zn}\left(\mu \mathrm{g} \mathrm{I}^{-1}\right)$ & 6.22 & 8.318 & 109.76 & 58.061 \\
\hline $\mathrm{Cu}\left(\mu \mathrm{g} \mathrm{I}^{-1}\right)$ & 1.78 & 0.338 & 2.73 & 0.612 \\
\hline As $\left(\mu g I^{-1}\right)$ & 0.19 & 0.078 & 0.62 & 0.354 \\
\hline $\mathrm{Cr}\left(\mu \mathrm{g} \mathrm{I}^{-1}\right)$ & 1.23 & 0.042 & 1.25 & 0.032 \\
\hline
\end{tabular}

(a) Sodium adsorption Ratio (SAR). an index of the sodium hazard to which the soil be subjected due to the use of a given irrigation water including the wastewater

The chemical and physical characteristics of the treated wastewater shown in Table 1, used in this experiment, are all within the range of the recommended maximum concentration, with the exception of Fe content, which is higher (WHO, 2006; Ayres and Westcot, 1989).

\section{RESULTS AND DISCUSSION}

The present work is dealing exclusively with the interactions of heavy metals which occured in a soil that had previously been cultivated with Brassica oleracea var. Gemmifera (Brussels sprouts), and irrigated with treated municipal wastewater (TMWW).

\subsection{The heavy metal interactions in the soil}

The regression coefficients of forty regression equations representing equal number of respective interactions between $\mathrm{Cd}, \mathrm{Pb}, \mathrm{Ni}, \mathrm{Cu}, \mathrm{Zn}$, and $\mathrm{Co}$ in the soil, are given in Table 2, respectively. The study of this table discloses that eleven interactions out of the forty, are statistically significant under both the effect of TMWW, the control, and mean treatments (average effect of TMWW and control), respectively. These results, show the consistency and the stability of these interactions, which are all synergistic, i.e. by increasing the level of the one interacting element increases the level of the other (Marschner, 2002). It can also be seen in the same table, that a number of other interactions are statistically significant only under the effect of the control, or under only the TMWW, or under the mean effect, while others are significant under the control and the mean or under TMWW and mean or finally under control or the TMWW, respectively. Similarly, a large number of interactions are non significant, under either of the above treatments, studied (Table 2).

Some of the afore mentioned interactions are" two-way" i.e. the increase of the level of the one interacting element results in the increase of the other, and vice versa, while others are "one-way" i.e. only the increase or decrease of one of the interacting elements increases or decreases the level of the other one (Kalavrouziotis et al., 2008a). 
Table 2. Coefficients of regression equations of heavy metal interactions, taking place in the soil under the influence of control, TMWW and Mean treatment effect, respectively cultivated with Brassica oleracea var. Gemmifera (Brussels sprouts)

\begin{tabular}{|c|c|c|c|c|}
\hline No & Interaction $^{1}$ & Control & TMWW & Mean Treatment \\
\hline 1 & $\mathrm{PbxZn}$ & $0.385 \mathrm{~ns}$ & $0.284 n s$ & $0.307 \mathrm{~ns}$ \\
\hline 2 & $\mathrm{ZnxPb}$ & $0.548^{*}$ & $0.171 \mathrm{~ns}$ & $0.411^{*}$ \\
\hline 3 & $\mathrm{PbxCu}$ & $0.656^{* *}$ & $0.879^{\star *}$ & $0.678^{\star \star}$ \\
\hline 4 & $\mathrm{CuxPb}$ & $0.470^{*}$ & $0.914^{\star \star \star}$ & $0.578^{* \star}$ \\
\hline 5 & $\mathrm{PbxCd}$ & $0.463^{*}$ & $0.382 \mathrm{~ns}$ & $0.347^{*}$ \\
\hline 6 & $\mathrm{CdxPb}$ & $0.117 n s$ & $0.311 \mathrm{~ns}$ & $0.293 \mathrm{~ns}$ \\
\hline 7 & $\mathrm{PbxNi}$ & $0.366 \mathrm{~ns}$ & $0.723^{* *}$ & $0.333^{*}$ \\
\hline 8 & $\mathrm{NixPb}$ & $0.626^{\star *}$ & $0.838^{* \star *}$ & $0.583^{* *}$ \\
\hline 9 & $\mathrm{PbxCo}$ & $0.597^{*}$ & $0.465^{*}$ & $0.529^{* *}$ \\
\hline 10 & $\mathrm{CoxPb}$ & $0.731^{* \star}$ & $0.539^{*}$ & $0.546^{\star *}$ \\
\hline 11 & CdxZn & $0.917^{* * *}$ & $0.893^{* \star \star}$ & $0.890^{* * *}$ \\
\hline 12 & ZnxCd & $0.890^{* * *}$ & $0.887^{\star \star \star}$ & $0.889^{* *}$ \\
\hline 13 & $\mathrm{CdxCu}$ & $0.047 \mathrm{~ns}$ & $0.288 \mathrm{~ns}$ & $0.255 \mathrm{~ns}$ \\
\hline 14 & CuxCd & $0.171 \mathrm{~ns}$ & $0.256 \mathrm{~ns}$ & $0.207 n s$ \\
\hline 15 & $\mathrm{CdxPb}$ & $0.117 \mathrm{~ns}$ & $0.331 \mathrm{~ns}$ & $0.293 \mathrm{~ns}$ \\
\hline 16 & $\mathrm{PbxCd}$ & $0.463^{*}$ & $0.382 \mathrm{~ns}$ & $0.347^{*}$ \\
\hline 17 & $\mathrm{CdxNi}$ & $0.028 \mathrm{~ns}$ & $0.043 \mathrm{~ns}$ & $0.021 \mathrm{~ns}$ \\
\hline 18 & NixCd & $0.182 \mathrm{~ns}$ & $0.249 \mathrm{~ns}$ & $0.181 \mathrm{~ns}$ \\
\hline 19 & CdxCo & $0.168 \mathrm{~ns}$ & $0.168 \mathrm{~ns}$ & $0.148 \mathrm{~ns}$ \\
\hline 20 & CoxCd & $0.483^{*}$ & $0.254 \mathrm{~ns}$ & $0.326 \mathrm{~ns}$ \\
\hline 21 & NixZn & $0.134 \mathrm{~ns}$ & $0.113 \mathrm{~ns}$ & $0.110 \mathrm{~ns}$ \\
\hline 22 & $\mathrm{ZnxNi}$ & $0.375 n s$ & $0.099 \mathrm{~ns}$ & $0.194 n s$ \\
\hline 23 & $\mathrm{NixCu}$ & $0.720^{* *}$ & $0.746^{* *}$ & $0.703^{* *}$ \\
\hline 24 & CuxNi & $0.303 n s$ & $0.698^{* *}$ & $0.416^{*}$ \\
\hline 25 & $\mathrm{NixPb}$ & $0.626^{* *}$ & $0.838^{* * *}$ & $0.583^{* *}$ \\
\hline 26 & $\mathrm{PbxNi}$ & $0.366 \mathrm{~ns}$ & $0.723^{* *}$ & $0.333^{*}$ \\
\hline 27 & NixCd & $0.182 \mathrm{~ns}$ & $0.249 \mathrm{~ns}$ & $0.181 \mathrm{~ns}$ \\
\hline 28 & $\mathrm{CdxNi}$ & $0.028 \mathrm{~ns}$ & $0.043 \mathrm{~ns}$ & $0.021 \mathrm{~ns}$ \\
\hline 29 & NixCo & $0.498^{*}$ & $0.148 \mathrm{~ns}$ & $0.259 \mathrm{~ns}$ \\
\hline 30 & CoxNi & $0.543^{*}$ & $0.433 \mathrm{~ns}$ & $0.213 \mathrm{~ns}$ \\
\hline 31 & CoxZn & $0.380 \mathrm{~ns}$ & $0.256 \mathrm{~ns}$ & $0.284 \mathrm{~ns}$ \\
\hline 32 & ZnxCo & $0.817^{* *}$ & $0.173 \mathrm{~ns}$ & $0.563^{* *}$ \\
\hline 33 & $\mathrm{CoxCu}$ & $0.215 \mathrm{~ns}$ & $0.525^{*}$ & $0.211 \mathrm{~ns}$ \\
\hline 34 & CuxCo & $0.259 \mathrm{~ns}$ & $0.363 \mathrm{~ns}$ & $0.189 \mathrm{~ns}$ \\
\hline 35 & $\mathrm{CoxPb}$ & $0.731^{* *}$ & $0.539^{*}$ & $0.546^{* \star}$ \\
\hline 36 & PbxCo & $0.597^{*}$ & $0.465^{*}$ & $0.529^{* *}$ \\
\hline 37 & CoxCd & $0.483^{*}$ & $0.254 n s$ & $0.326^{*}$ \\
\hline 38 & CdxCo & $0.168 \mathrm{~ns}$ & $0.168 \mathrm{~ns}$ & $0.148 n s$ \\
\hline 39 & CoxNi & $0.543^{*}$ & $0.433 n s$ & $0.213 \mathrm{~ns}$ \\
\hline 40 & NixCo & $0.498^{*}$ & $0.148 \mathrm{~ns}$ & $0.259 \mathrm{~ns}$ \\
\hline
\end{tabular}

${ }^{1}$ In the regression equation, always the first element of any one of the above interactions represents the independent variable $(X)$ and the second the dependent $(Y)$. The interactions with bold letters are statistically significant and "two-way". $\left({ }^{*}\right),\left({ }^{* *}\right),\left({ }^{* * *}\right)$ statistically significant at $\mathrm{p}_{0.05}$, $\mathrm{p}_{0.01}, \mathrm{p}_{0.001}$ level of significance, respectively. $n s$ : non significant.

The following representative heavy metal interactions will be examined bellow.

\subsubsection{PbxCu}

An interaction of special environmental importance. While $\mathrm{Pb}$ is neither an essential or a beneficial element, but basically a toxic metal, it interferes with the availability of an essential 
micronutrient, i.e. the $\mathrm{Cu}$, by acting on it synergistically, thus increasing its level in the soil (Figure 1A). These two elements, are interrelated between themselves, in a "two-way" interaction (Figure 1B) where the increase of the $\mathrm{Cu}$ level results in the increase of the $\mathrm{Pb}$ concentration in the soil. The environmental significance of this interaction is based on the fact that the presence of either one of these two heavy metals in the soil, further enhances mutually the concentration of the other, which at very high levels in the soil, may affect adversely plant growth and the agroecological environment.
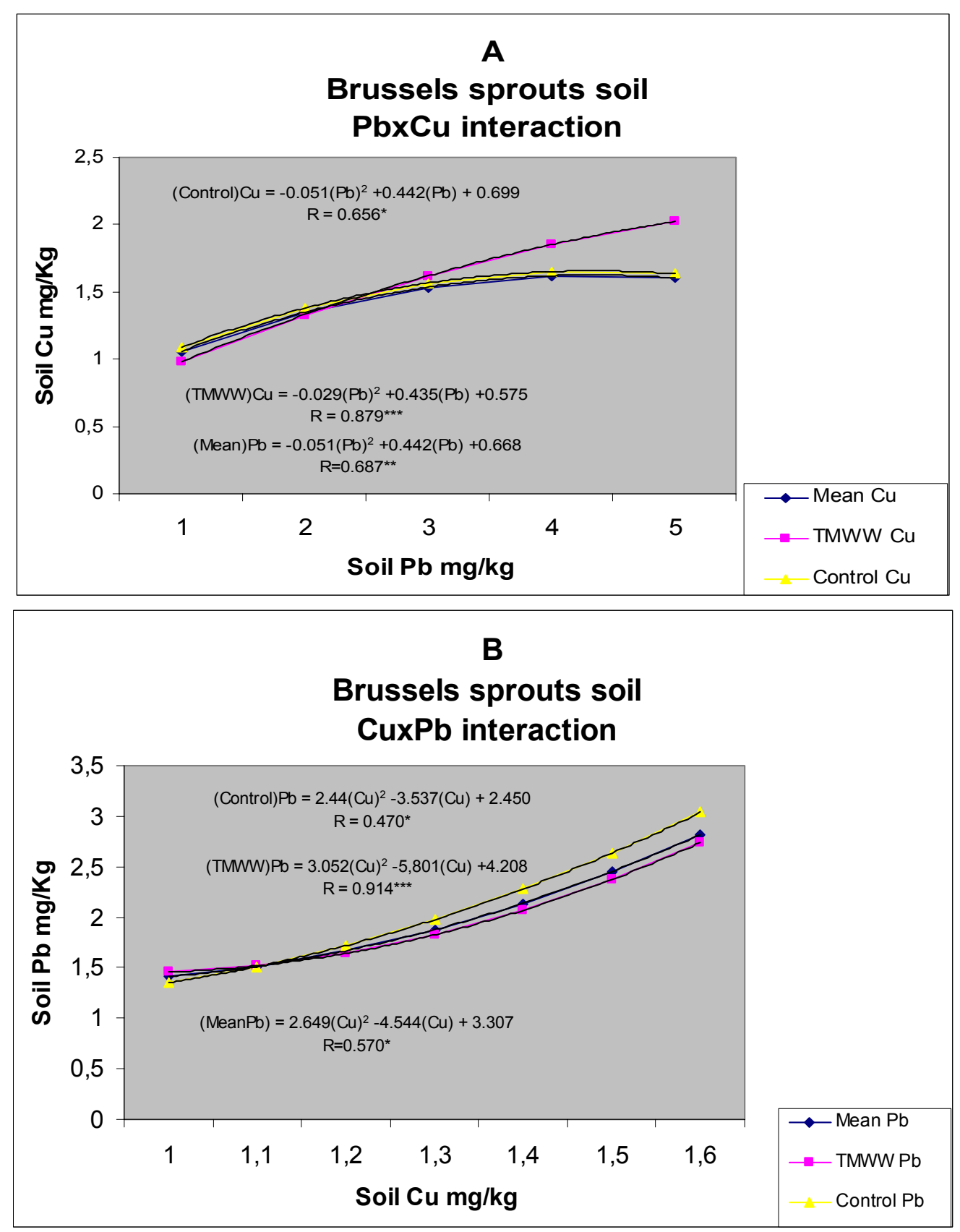

Figure 1. Interrelationships of soil DTPA extractable $\mathrm{Pb}$ and $\mathrm{Cu}$ under the effect of: a) TMWW b) Control and c) Mean treatment, respectively

Closer examination of Figures $1 \mathrm{~A}$ and $1 \mathrm{~B}$ discloses that though there is a trend of an increasing effect of TMWW on the level of $\mathrm{Cu}$ with the increase of $\mathrm{Pb}$ concentration (Figure $1 \mathrm{~A}$ ), and a similar effect of the control on the level of the $\mathrm{Pb}$, with the increase of $\mathrm{Cu}$ concentration (Figure 1B), the difference, however, in the concentration of either of these elements, is statistically non-significant, neither under the TMWW or the control,respectively. These results, show therefore that both of the treatments studied, affect more or less similarly 
the bioavailable level of either $\mathrm{Cu}$ or $\mathrm{Pb}$ in the soil during their respective interactions, and consequently their effect on the interactions $\mathrm{PbxCu}$ or $\mathrm{CuxPb}$, is similar.

Unfortunately, our knowledge about these interactions is very poor, and more work is necessary to throw more light on this interrelationship, which may be intensified under the TMWW effect, since the later will eventually be used as a alternative source of the irrigation water.

The interactions under consideration, must be studied in connection to the $\mathrm{pH}$ changes brought about by the TMWW (Kalavrouziotis et al., 2008b) as well as in relation to organic compounds contained in the TMWW. Both $\mathrm{Cu}$ and $\mathrm{Pb}$ are complexed by the organic matter (Stevenson and Cole, 1999) and their solubility is very highly affected by the $\mathrm{pH}$ changes (Kabata-Pendias and Pendias, 1995).

The $\mathrm{Pb}$ is least mobile heavy metal in the soil, and the characteristic localization near the surface of most soils is primarily related to the surface accumulation of organic matter. Thus according to the above workers the greatest $\mathrm{Pb}$ accumulation is found in organically rich layers of soil. This is in agreement with the statement by Hughes et al., (1980), according to which steadily increasing amounts of $\mathrm{Pb}$ in surface soils of various terrestrial systems have been reported.

The proximity of both $\mathrm{Pb}$ and $\mathrm{Cu}$ accumulation, possibly favors the synergistic interaction between these two heavy metals, found in the present work.

\subsubsection{CoxPb}

This interaction was found to be "two-way" synergistic (Figures $2 \mathrm{~A}$ and $2 \mathrm{~B}$ ). Similar results were obtained in another work with Brassica oleracea var. Italica(broccoli), it was found that the above interaction was "two way"synergistic in the the plants of this vegetable, irrespective of the plant parts (mean TMWW effect) (Kalavrouziotis et al., 2009).
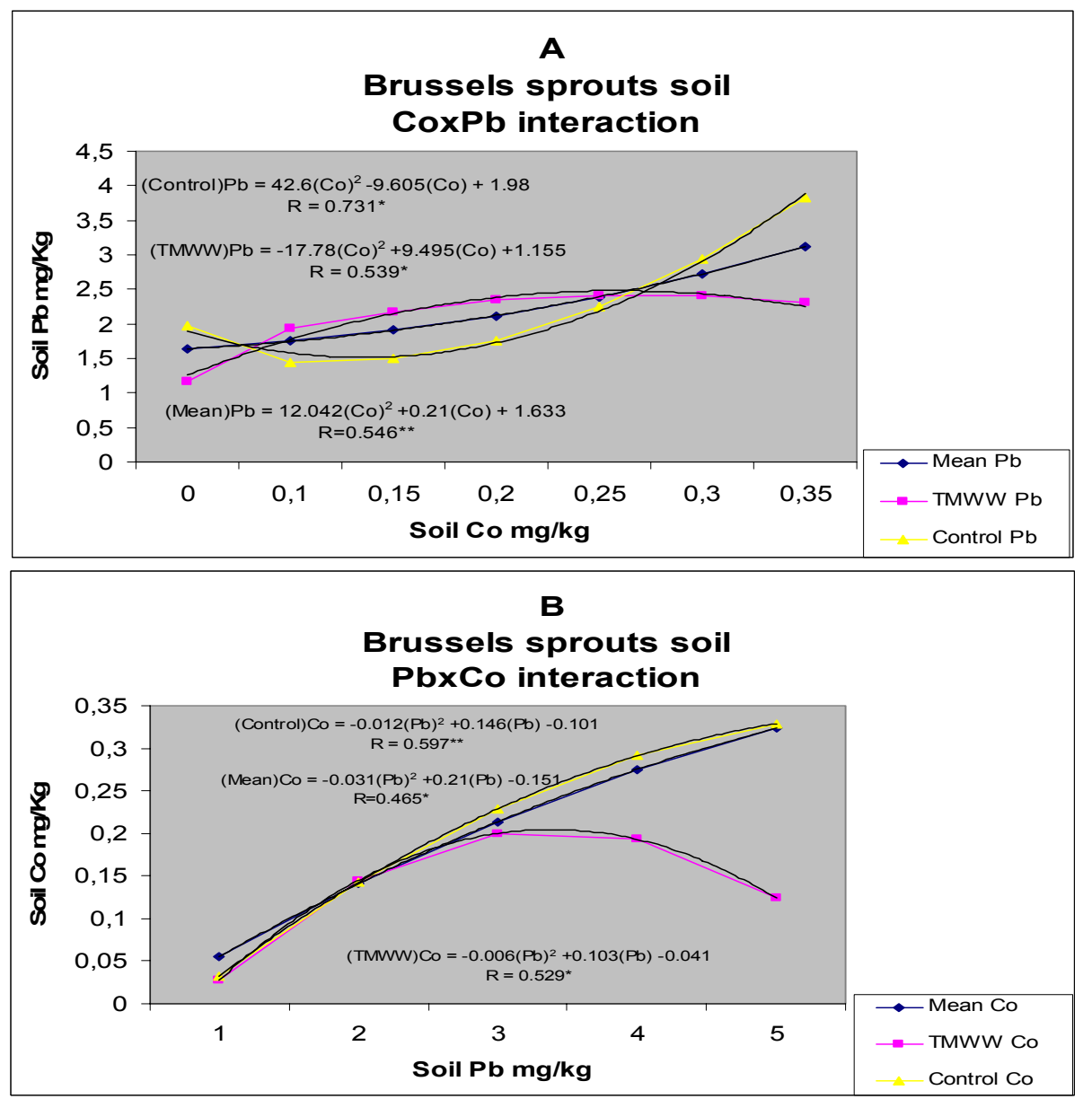

Figure 2. Interrelationships of soil DTPA extractable Co and Pb under the effect of: a) TMWW b) Control and c) Mean treatment, respectively 
The findings of the present work in relation to the CoxPb interaction taking place in the soil which had been cultivated with Brassica oleracea var. Gemmifera (Brussels sprouts), are in agreement with the above reported results related to broccoli, thus reflecting the consistency of the occurrence of the above interaction.

Figures $2 \mathrm{~A}$ and $2 \mathrm{~B}$ however, show that both the level of the $\mathrm{Pb}$ and $\mathrm{Co}$, respectively, decreases under the effect of TMWW with the corresponding increase of Co at evels $>0.25 \mu^{-1}$ (Figure $2 \mathrm{~A}$ ), and similarly of $\mathrm{Pb}$, at levels $>3.0 \mu \mathrm{g} \mathrm{g}^{-1}$ (Figure $2 \mathrm{~B}$ ), respectively.

These findings suggest that under the TMWW, the interactions $\mathrm{CoxPb}$ or $\mathrm{PbxCo}$ become antagonistic at the higher levels of the $\mathrm{Co}$ and $\mathrm{Pb}$ concentration in the soil, as reported for Broccoli plants (Kalavrouziotis et al., 2009)

\subsubsection{CdxZn}

According to Kabata-Pendias and Pendias (1995), the CdxZn interaction has been reported as both antagonistic and synergistic. The synergism was found in rice by Kitagishi and Vamane (1981) who explained the occurrence of this interaction in terms of $\mathrm{Zn}$ competition for $\mathrm{Cd}$ sites, which results in an increase of $\mathrm{Cd}$ solubility and $\mathrm{Cd}$ translocation from roots to shoots. Wallace et al. (1980) also reported that in the presence of high $\mathrm{Zn}$ level. Cd accumulated in roots, thus suggesting the synergistic nature of this interaction. But Lagerwerff and Biersdorf (1971) had earlier reported that the CdxZn interaction was found to be antagonistic during its uptake-transport process.In fact they found that increasing concentration of $\mathrm{Zn}$ suppressed Cd uptake at low Cd concentration. It appears that the $\mathrm{Cd} / \mathrm{Zn}$ ratio is the governing factor of the CdxZn synergism or antagonism (Kabata-Pendias and Pendias, 1995).

In the present work, the CdxZn interaction in the soil was synergistic and "two-way" (Figures $3 \mathrm{~A}$ and $3 \mathrm{~B}$ ). As shown in Figure 3B, the Cd concentration increases very sharply with the increase of the $\mathrm{Zn}$ level, irrespective of the treatment effect. According to Alloway (1995), from the geochemical point of view, $\mathrm{Cd}$ is very closely related to $\mathrm{Zn}$, as both elements have similar ionic structures and electronegativities. Also, they show the same tendency with respect to their downward movement within the soil profile. This seem to be in line with the reported statement that $\mathrm{Zn}$ exhibits greater inhibitory effect than all the other metals on $\mathrm{Cd}$ absorption on the solid phase of soil, thereby indirectly contributing to the latter's availability (Kabata-Pendias and Pendias, 1995).

The above interaction was also found to be antagonistic, and concomitantly occurring in the "root-leaf" pathway of Brussels sprouts plants, under the effect of TMWW (Kalavrouziotis and Koukoulakis 2009), thus agreeing with the findings of Lagerwerff and Biersdorf (1971).

These seemingly controversial results signify the complexity of the interactions and the necessity of more scrupulous and detailed work that must still be done to fully explain them.

The geochemical similarities between $\mathrm{Cd}$ and $\mathrm{Zn}$, may possibly explain their synergistic interrelationship in the soil, reported in this work. However, environmentally, the CdxZn interaction is very important. Thus, the increase of $\mathrm{Cd}$ in the soil by $1 \mathrm{mg} \mathrm{kg}^{-1}$ under the TMWW (Figure 2A), corresponds to an increase of $\mathrm{Zn}$ equal to $0.79 \mathrm{mg} \mathrm{kg}^{-1}$, while for each increase of soil $\mathrm{Zn}$ by $1 \mathrm{mg} \mathrm{kg}^{-1}$, the $\mathrm{Cd}$ increases on the average by $0.71 \mathrm{mg} \mathrm{kg}^{-1}$ (Figure $3 A$ ). The increase, especially of $\mathrm{Cd}$, is high enough to potentially cause problems to plants and humans, and shoud be taken into consideration when reusing TMWW for the irrigation of crops.

The $\mathrm{Cd}$ is a heavy metal which when present in the food even in suboptimal levels, may cause chronic accumulation in kidneys and dysfunction, if its concentration increases in the kidney cortex above to $200 \mathrm{mg} \mathrm{kg}^{-1}$ of fresh weight (Fassett,1980). 

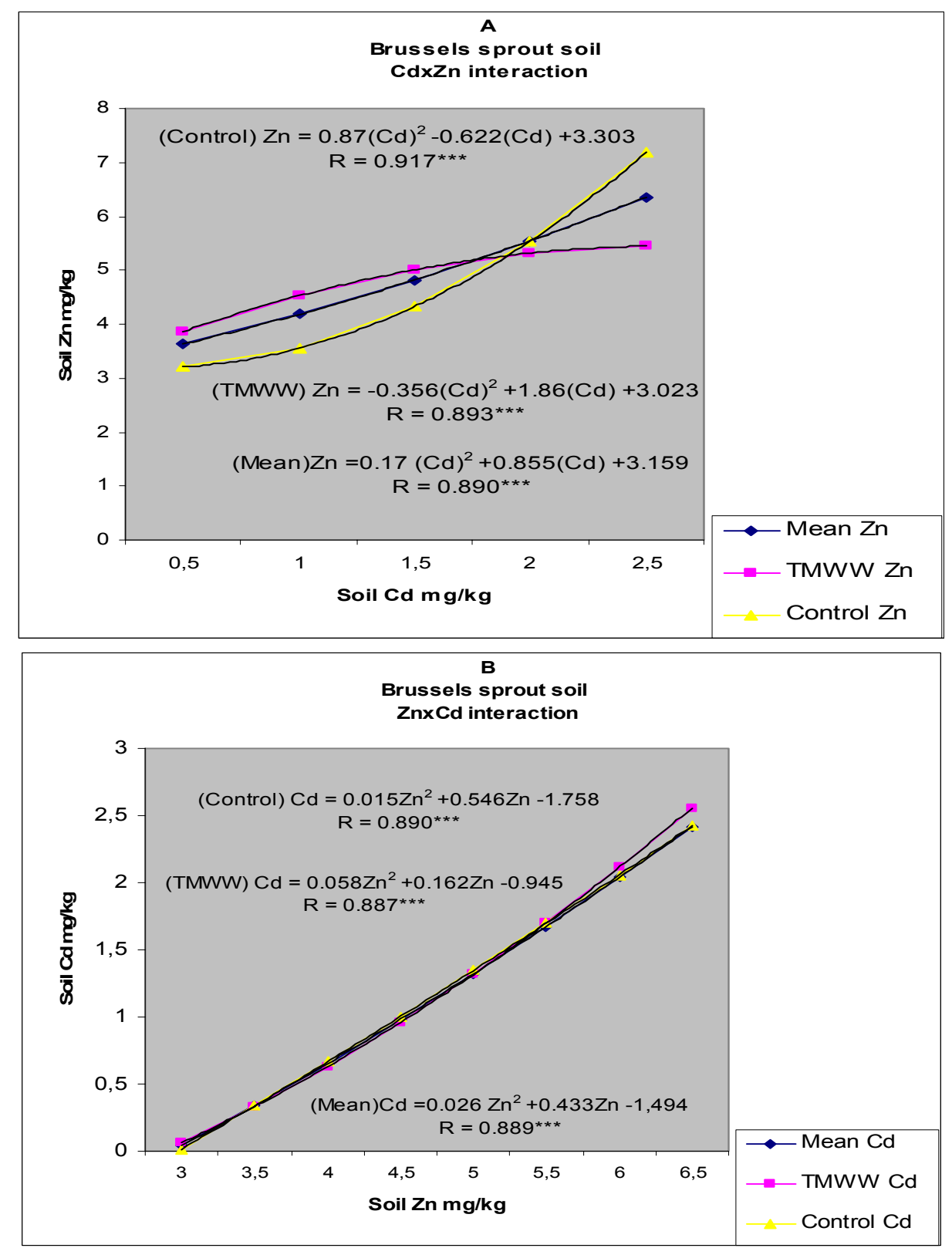

Figure 3. Interrelationships of soil DTPA extractable $\mathrm{Cd}$ and $\mathrm{Zn}$ under the effect of: a) TMWW b) Control and c) Mean treatment respectively

\subsection{4 $\mathrm{NixCu}$}

This interaction was found to be in the soil synergistic, as the increase of the Ni level is followed by a corresponding increase of $\mathrm{Cu}$, irrespective of the treatment effect (Figure 4).Conversely, according to our unpublished data, the $\mathrm{NixCu}$ interaction has been found in Brussels sprouts leaves antagonistic under the Control, and "antagonistic-synergistic" under TMWW, the latter contributing negatively to the plant, basically being antagonistic.

Unfortunately, the available bibliographic information about this interaction is very limited. According to Cataldo et al. (1978) the absorption of $\mathrm{Ni}$ by soybean roots and its translocation to roots and shoots was inhibited by the presence of $\mathrm{Cu}$, suggesting that these two elements may be interacting antagonistically. Nevertheless, the results of the present work, showed that there is a great need need for more work based on specially designed experiments for the elucidation of the afore mentioned interaction. 


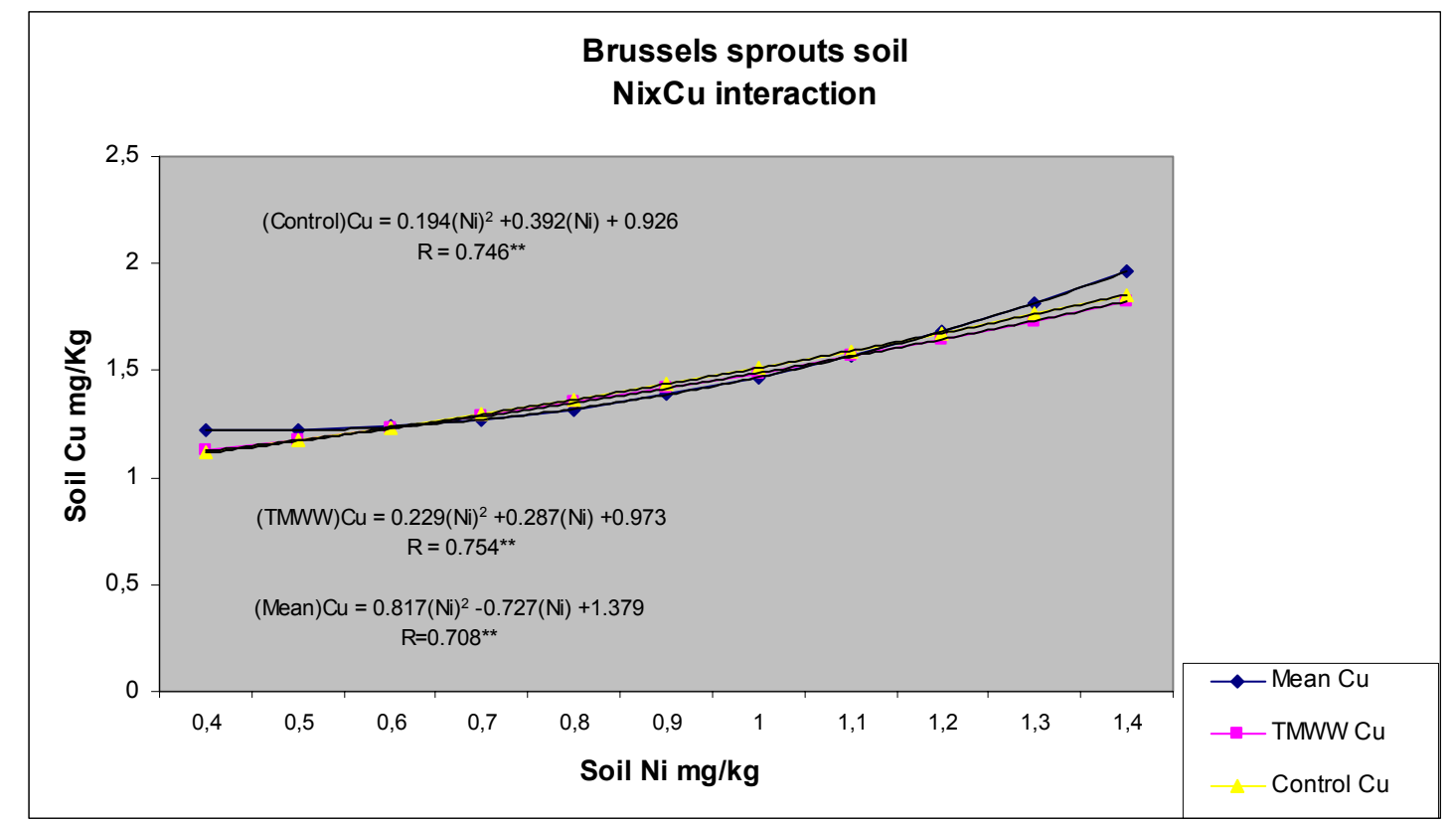

Figure 4. Interrelationships of soil DTPA extractable $\mathrm{Ni}$ and $\mathrm{Cu}$ under the effect of: a) TMWW b) Control and c) Mean treatment respectively

The $\mathrm{Ni}$ and $\mathrm{Cu}$, apart from being characterized as heavy metals, they are also essential plant nutrients. In fact the Ni has recently been included in the essential elements (Brown, 2007). Therefore, the interaction NixCu is directly related to plant growth and development and their possible synergism in the soil, may mutually increase their concentration, thus favoring plant growth, and eventually, the environment.

\subsubsection{NixPb}

Results related to the above interaction, reported in previous work (Kalavrouziotis et al., 2008b) showed that this interaction under both the effect of TMWW and Control, was found to be "two-way" and synergistic, in a soil cultivated with Brassica oleracea var. Italica (broccoli). Also, in another unpublished work, the NixPb interaction was shown to be synergistic in broccoli leaves under the TMWW and control, respectively, but antagonistic in the heads under the TMWW, where the $\mathrm{Pb}$ decreased, with the increase of $\mathrm{Ni}$ up to $5 \mu \mathrm{g} \mathrm{g}^{-1}$, and it increased at an Ni concentration $>5 \mu \mathrm{g} \mathrm{g}^{-1}$.

Similarly, in the present work this interaction (NixPb) was also found to be "one-way" synergistic in the soil, which was cultivated with Brassica oleracea var. gemmifera (Brussels sprout) (Figure 5).

Thus, the results of the present work seem to confirm the consistency of the synergism of the $\mathrm{NixPb}$ interaction in the soil, in the leaves, as well as $\mathrm{n}$ the edible plant part, but at higher than $5 \mu \mathrm{g} \mathrm{g}^{-1}$ level of $\mathrm{Ni}$.

As shown in Figure 5, the differences observed in the concentration of $\mathrm{Pb}$ with the increasing levels of $\mathrm{Ni}$, under the effect of the control, TMWW and Mean treatment, respectively, are statistically non significant according to t-test. This means that both the TMWW and Control affect the NixPb interaction more or less similarly.

As far as the relation of this interaction to the environment, it is of interest to note that the increase of $\mathrm{Pb}$ as a result of the synergistic effect of $\mathrm{Ni}$, may be of concern, if the $\mathrm{Pb}$ level in the soil increases to toxic levels, as result of high levels of $\mathrm{Ni}$ that may possibly occur in the soil due to possible pollution with $\mathrm{Ni}$. 


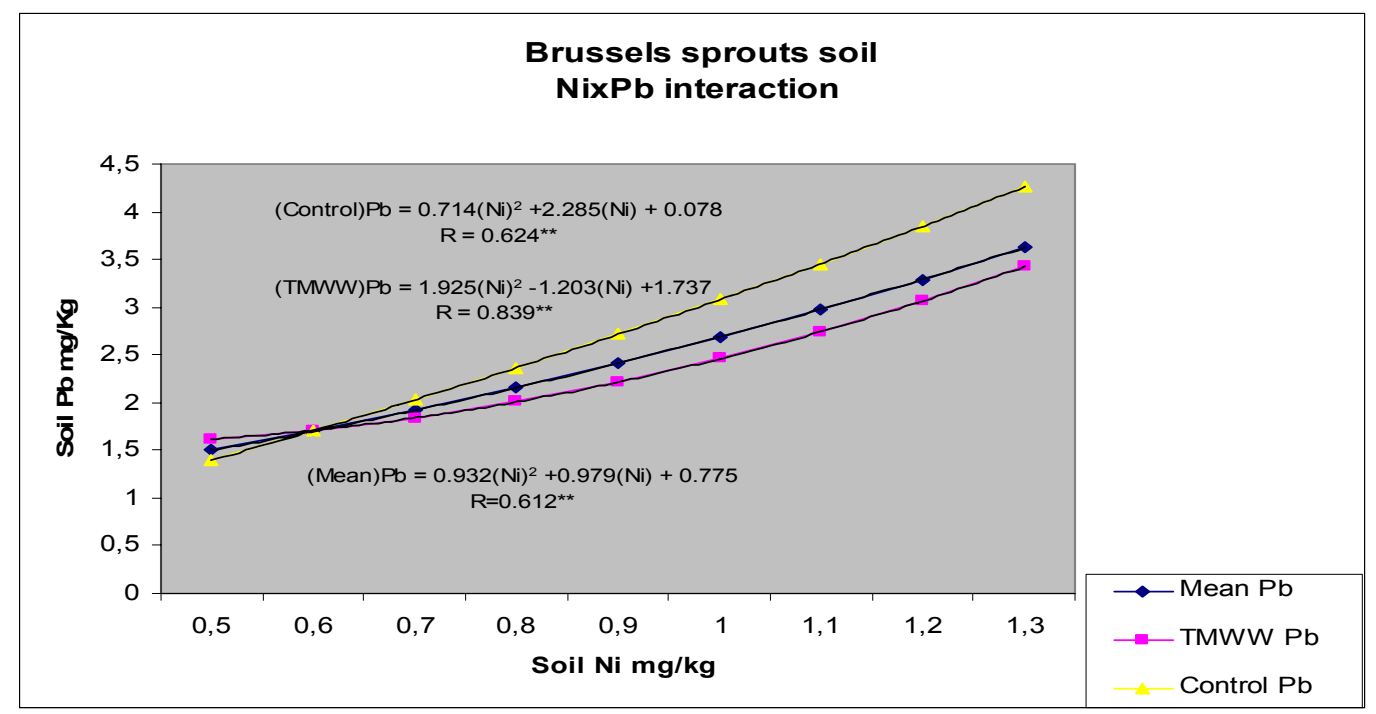

Figure 5. Interrelationships of soil DTPA extractable $\mathrm{Ni}$ and $\mathrm{Pb}$ under the effect of: a) TMWW b) Control and c) Mean treatment respectively

\section{CONCLUSIONS}

Of the 40 soil heavy metal interactions taking place between $\mathrm{Pb}, \mathrm{Ni}, \mathrm{Co}, \mathrm{Cu}, \mathrm{Cd}$ and $\mathrm{Zn}$, under the respective effect of TMWW and Control, only 36 were statistically significant, being distributed on the basis of the applied treatments, as follows: a) under TMWW: 15 or $37.5 \%$, and b) under the Control 21 or $52.5 \%$.

Thus, most of the statistically significant interactions took place under the effect of the control, and less under the TMWW. Also, 11 of these interactions or $27.5 \%$ were found to be concomitantly occurring under TMWW and Control, respectively. This, indicated the consistency and stability of the occurrence of these interactions.

The general conclusion was that on the average, the effect of TMWW on the above interactions did not differ significantly from that of the control. Therefore, from this point of view, the TMWW could be used for vegetable irrigation, provided that the necessary measures are taken for minimizing the health risk involved, probably by improving the treatment of the wastewater in the Biological Treatment Plant.

Most of the heavy metal interactions in the soil, were found to be "two-way", synergistic. This synergism, however, when it refers to heavy metals, it may be a cause of serious concern from the environmental and health point of view, since It may increase the level of toxic elements, such as for example of $\mathrm{Cd}$ and $\mathrm{Pb}$.

More detailed experimental work is necessary to further elucidate the relations of heavy metals with the environment, and health, under the effect of the TMWW reuse.

\section{ACKNOWLEDGEMENTS}

We express our thanks to Dr Pantazis V. for the preparation of the drawings.

\section{REFERENCES}

Alloway B.J., (1995). Heavy metals in soils, Blackie Academic and Professional, An imprit of Chapman and Hall, London.

AOAC (1996). Official methods of Analysis of Association of Official Agricultural Chemists (AOAC) International. $16^{\text {th }}$ ed. Publ. International Suite AOAC 481 North Frederick Avenue Gaithersburg, Maryland 2027 - 2417 U.S.A.

Ayres R.S. and Wescot D.W., (1985). Water quality for agriculture, FAO Irrigation and drainage paper 29-Rev-1, FAO UN Rome.

Brown P.H., Nickel In: Barker A.V. and Pilbeam D.J., (eds), (2007). Handbook of Plant Nutrition, CRC Taylor and Francis Group Boca Raton, p395.

Cataldo D.A., Garland T.R. and Wildung R.E., (1978) Nickel in plants, II Distribution and chemical form in soybean plants Plant physiol., 62, 566-570. 
Chang A.C., Page A.L., Asano T., Hespanhol J., (1998). Evaluating methods of establishing human health-related chemical guidelines for crop land applications of municipal wastewater. In: Asano. T,(ed) Wastewater Reclamation and reuse Technomic Publishing, Lancaster, Basel, USA.

Fassett, D.W. (1980) Cadmium In: Metals in the environment, Waldron, H.A. (ed). Academic Press, London, pp. 61-110.

Hughes M.K., Lepp N.W. and Phipps D.A. (1980) Aerial heavy metal pollution and terrestrial ecosystems, Adv. Ecol. Rco., 11, 217-327.

Kabata-Pendias A. and Pendias H. (1995) Trace elements in Soils and plants, $2^{\text {nd }}$ edition CRC Press, Boca Raton Ann Arbor, London.

Kalavrouziotis I.K., Robolas P.K., Koukoulakis P.H. and Papadopoulos A.H. (2008). Effects of municipal reclamed water on the macro-, micronutrients of soil and Brassica oleracea var. Italica, and Brassica oleracea var. gemmifera, J. Agric. Water Management, 95(4), 419 - 426.

Kalavrouziotis I.K., Koukoulakis P.H., Robolas P.K., Papadopoulos A.H. and Pantazis V., (2008a). Essential plant nutrients interactions in a soil cropped with Brassica oleracea var. Italica, irrigated with Treated Municipal Wastewater, and their environmental implications, Fresenius Environmental Bulletin, 17(9a), 1272-1280.

Kalavrouziotis I.K., Koukoulakis P.H., Robolas P.K., Papadopoulos A.H. and Pantazis V., (2008b). Interrelationships of heavy metals, macro and micronutrients, and properties of soil cultivated with Brassica oleracea var. Italica (Broccoli) under the effect of treated municipal reclaimed wastewater, Water, Air and Soil pollution, 190(1-4), 309-321.

Kalavrouziotis I.K., Koukoulakis P.H., Sakellarkou-Makrantonaki M., Papanikolaou C., (2009). Effect of treated municipal wasrewater on the essentaia nutrient interactions in the plant of Brassica oleracea var. Italica, Desalination, 242, 297-312.

Kalavrouziotis I.K. and Koukoulakis P.H., (2009). Distribution of elemental interactions in Brussels sprouts plants, under the treated municipal wastewater, J. Plant Interactions, 4(2), 1-13.

Kitagishi K. and Yamane I., (1981). Heavy metal pollution in soils of Japan. Japan Science Society Press, Tokyo.

Lagerwerff J.V. and Biersdorf G.T., (1971) Trace Subs, Environmental health, 5, 515-522.

Lanyon L.E. and Heald, W.R. (1982) Magnesium, calcium, strontium and barium, In: Methods of Soil Analysis, part II ASA, Page A.L. et al. (Eds), Madison Wisconsin.

Marschner H. (2002) Mineral Nutrition of Higher Plants, $2^{\text {nd }}$ Edition. Academic Press, Amsterdam.

Olsen S.R., Cole C.V., Watanabe P.S. and Dean L.A. (1954). Estimation of available phosphorus in soils by extraction with sodium bicarbonate Circular, 939, USDA

Page A.L., Miller R.H. and Keeney D.R. (1982). Methods of soil analysis II. Chemical and microbiological properties $2^{\text {nd }}$ Edition ASA, SSSA, Madison Wisconsin, USA p. 1159.

Phipps D.A. (1981) Chemistry and biochemistry of trace metals in biological systems In: Effects of heavy metal pollution on plants, Lepp N.W. (ed), Applied Science Publishers, London, UK pp1-54.

Richards L.A. (1954) Diagnosis and Improvement of Saline and Alkali Soils, Handbook No 60, USDA Washington D.C. p84.

Sakata M., (1987). Movement and neutralization of alkaline leachate at coal ash disposal sites, Environ. Sci. Tech., 21, 771-277.

Sheikh B., Cort R., Cooper R.C. and Jacques R.C., (1998). Tertiary treated reclaimed water for irrigation of raw-eaten vegetables. In: Asano, T. (ed) Wastewater reclamation reuse. Technomic Publishing, Lancaster, Basel, USA.

APHA (1995) Standard methods for the Examination of water and wastewater Method 3110, $19^{\text {th }}$ edition, American Public Health Association, Washington D.C. USA.

Stevenson F.J. and Cole M.A. (1999) Cycles of soil Carbon, Nitrogen, Phosphorus, Sulfur, Micronutrients, $2^{\text {nd }}$ eddition, John Wiley and Sons Inc. New York.

Wallace A., Romney, E.M. and Alexander G.V. (1980) Zn-Cd interactions of the availability of each bush bean plant growth in solution culture, J. Plant Nutrition, 2, 51-60.

WHO (2006) Guidelines for the safe use of wastewater, excreta and greywater, Vol. 2, WHO, Geneva. 